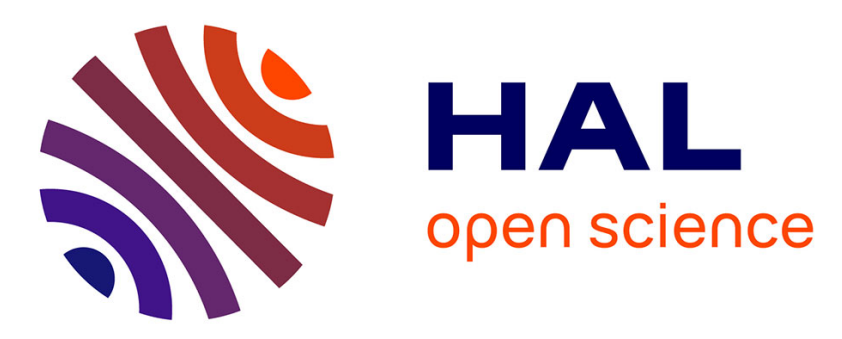

\title{
Carbonyl sulfide (OCS) variability with latitude in the atmosphere
}

G. Krysztofiak, Yao Veng Té, Valéry Catoire, Gwenaël Berthet, Geoffrey C. Toon, Fabrice Jégou, Pascal Jeseck, C Robert

\section{- To cite this version:}

G. Krysztofiak, Yao Veng Té, Valéry Catoire, Gwenaël Berthet, Geoffrey C. Toon, et al.. Carbonyl sulfide (OCS) variability with latitude in the atmosphere. Atmosphere-Ocean, 2015, 53, pp.89-101. 10.1080/07055900.2013.876609 . insu-00906943

\section{HAL Id: insu-00906943 https://hal-insu.archives-ouvertes.fr/insu-00906943}

Submitted on 20 Nov 2013

HAL is a multi-disciplinary open access archive for the deposit and dissemination of scientific research documents, whether they are published or not. The documents may come from teaching and research institutions in France or abroad, or from public or private research centers.
L'archive ouverte pluridisciplinaire $\mathbf{H A L}$, est destinée au dépôt et à la diffusion de documents scientifiques de niveau recherche, publiés ou non, émanant des établissements d'enseignement et de recherche français ou étrangers, des laboratoires publics ou privés. 


\title{
Carbonyl sulfide (OCS) variability with latitude in the atmosphere
}

\author{
Gisèle Krysztofiak $^{1}$, Yao Veng Té ${ }^{2}$, Valéry Catoire ${ }^{1^{*}}$, Gwenaël Berthet ${ }^{1}$, \\ Geoffrey C. Toon ${ }^{3}$, Fabrice Jégou ${ }^{1}$, Pascal Jeseck ${ }^{2}$ and Claude Robert ${ }^{1}$.
}

1 LPC2E, UMR 7328 CNRS-Université d'Orléans, 3A Avenue de la Recherche Scientifique, 45071 Orléans Cedex 2, France

${ }^{2}$ LPMAA, UMR 7092 CNRS-Université Paris 06, IPSL, 75005, Paris, France

3 Jet Propulsion Laboratory, California Institute of Technology, Pasadena, CA 91109, USA.

*corresponding author: Valery.Catoire@cnrs-orleans.fr

Keywords:

Abstract

Carbonyl sulfide (OCS) is an important precursor of sulfate aerosols and consequently a key species in stratospheric ozone depletion. SPIRALE and SWIR balloon-borne instruments have flown in the tropical region and in the Arctic polar region, and ground-based measurements have been performed by QualAir FTS instrument in Paris. Partial and total columns and vertical profiles have been obtained to study the OCS variability with altitude, latitude and season. The annual total column variation in Paris reveals a seasonal variation with a maximum in April-June and a minimum in November-January. Total column measurements above Paris and from SWIR balloon-borne instrument are compared with several MkIV measurements, several NDACC stations, aircraft, ship and balloon measurements to highlight the OCS total column decrease from tropical to polar latitudes. OCS high resolution in situ vertical profiles have been measured for the first time in the altitude range between 14 and $30 \mathrm{~km}$ at tropical and polar latitudes. OCS profiles are compared with ACE satellite measurements and show good agreement. Using OCS: $\mathrm{N}_{2} \mathrm{O}$ correlation from SPIRALE, OCS stratospheric lifetime has been accurately determined. We find a stratospheric 
lifetime of $70 \pm 20$ years at polar latitude and $58 \pm 14$ years at tropical latitude leading to a global stratospheric sink of $54 \pm 14 \mathrm{Gg} \mathrm{S} \mathrm{yr}^{-1}$. 


\section{Introduction}

Carbonyl sulfide (OCS) is the most abundant sulfur-containing compound in the atmosphere. OCS is mainly emitted into the troposphere by biogenic processes from oceans, directly and indirectly by oxidation of DMS and $\mathrm{CS}_{2}$. OCS is also emitted directly by biomass burning (10 to $20 \%$ of the overall sources; Notholt et al., 2003) and by soil and wetlands (Kettle et al., 2002a). In addition, OCS can be released by anthropogenic sources, particularly from $\mathrm{CS}_{2}$ oxidation, itself released by industry and use of natural gas. Uptake by vegetation, soils and reaction with the hydroxyl radicals are the main tropospheric sinks in the lower troposphere (Kettle et al., 2002a). Due to its relatively low reactivity in the troposphere, OCS can reach the stratosphere and can react with $\mathrm{OH}$ or $\mathrm{O}$ radicals by the following reactions:

$\mathrm{OCS}+\mathrm{OH} \rightarrow \mathrm{CO}_{2}+\mathrm{HS}$

$\mathrm{OCS}+\mathrm{O} \rightarrow \mathrm{CO}+\mathrm{SO}$

But the main OCS sink in the stratosphere is the photolysis reaction (Chin and Davis, 1995; Sander et al., 2011):

$\mathrm{OCS}+\mathrm{h} v \rightarrow \mathrm{CO}+\mathrm{S}(\lambda \leq 300 \mathrm{~nm})$

Produced sulfur compounds $\mathrm{S}, \mathrm{HS}$ and $\mathrm{SO}$ are rapidly oxidized by $\mathrm{O}_{2}, \mathrm{O}, \mathrm{OH}$, $\mathrm{O}_{3}$ or $\mathrm{HO}_{2}$ to form the product $\mathrm{SO}_{2}$. Finally, $\mathrm{SO}_{2}$ is converted into $\mathrm{H}_{2} \mathrm{SO}_{4}$ by reaction with $\mathrm{OH}$ or heterogeneously. $\mathrm{H}_{2} \mathrm{SO}_{4}$, is the principal gaseous precursor for stratospheric sulfate aerosol (Chin and Davis et al., 1993, 1995), which catalyzes ozone depletion. However, the OCS mass budget and its contribution to the stratospheric aerosol layer are difficult to estimate (Wilson et al., 2008), mainly due to recurrent moderate volcanic eruptions disrupting the sulfur burden in the stratosphere by direct $\mathrm{SO}_{2}$ injection into the 
stratosphere (Vernier et al., 2011). More OCS measurements at different latitudes during non-volcanic periods could reduce the uncertainties on the OCS mass budget.

The international Network for the Detection of Atmospheric Composition Change (NDACC) (http://www.ndsc.ncep.noaa.gov/) is composed of several stations providing OCS measurements, at ground level principally, of total column measurements or surface concentration. Additionally, OCS measurements have been obtained from several aircraft campaigns from ground to $14 \mathrm{~km}$ altitude maximum, principally by whole air sampling (Simpson et al., 2010) during ARCTAS (Harrigan et al. 2011), INTEX (Blake et al., 2007; Barletta et al., 2009) and TRACE-P (Blake et al., 2004). Only stratospheric balloons provide an altitude range from $10 \mathrm{~km}$ to $40 \mathrm{~km}$ altitude. However only few balloon campaigns have led to OCS measurements, and mainly by remote sensing instruments using solar occultation spectrometry (e.g. MkIV, Toon, 1991) during for example ACE validation (Velazco et al., 2011), STRAT, POLARIS, SOLVE I and II campaigns (Leung et al., 2002), or by whole air sampling (Engel and Schmidt, 1994). There are no OCS measurements by an in situ high resolution technique.

Three large balloon campaigns have been recently conducted. One from Teresina $\left(5.1^{\circ} \mathrm{S}, 42.9^{\circ} \mathrm{W}\right)$ in North-East of Brazil in June 2008 in the frame of the SCOUT-O3 FP7 European Commission integrated project. And two from Esrange $\left(67.9^{\circ} \mathrm{N}-21.1^{\circ} \mathrm{E}\right)$ in the framework of the StraPolÉté project (http://strapolete.cnrs-orleans.fr/) during the International Polar Year from 2 August to 7 September 2009, and in the framework of the ENRICHED project (http://www.lpc2e.cnrs-orleans.fr/ enriched/) from 31 March to 23 April 2011. Here we analyze OCS measurements conducted by SPIRALE (Moreau et al., 2005) and SWIR (Té et al., 2002) balloon instruments participating in these campaigns. In addition, recent OCS total columns from ground-based measurements in 
Paris by the QualAir FTS instrument provide new reference information at mid-latitude $\left(48.9^{\circ} \mathrm{N}, 2.4^{\circ} \mathrm{E}\right)$.

The paper is organized as follows. The QualAir FTS, SPIRALE and SWIR instruments, the Teresina and Esrange balloons flights and the ground based measurements over Paris are described in Section 2. Section 3 presents the observations performed during the two balloon campaigns and their comparisons with other results. Then, we discuss about the role of OCS in the stratospheric sulfur budget.

\section{Instrument description}

\section{a QualAir Fourier transform Spectrometer (QualAir FTS)}

The Fourier transform spectrometer of the QualAir platform (QualAir FTS) is a Michelson interferometer of the model IFS 125HR from Bruker Optics (see http://www.brukeroptics.com). At full spectral resolution $\left(0.0024 \mathrm{~cm}^{-1}\right)$, the maximum optical path difference is $258 \mathrm{~cm}$. Associated with infrared optical elements $\left(\mathrm{CaF}_{2}\right.$ window and beamsplitter, InSb detector), this spectrometer is adapted for ground-based atmospheric measurements (see Té et al. (2010) for more details). Connected to a suntracker (model A547 from Bruker Optics) on a roof terrace, the QualAir FTS operates in the solar absorption configuration and allows for detecting of a large number of atmospheric pollutants $\left(\mathrm{CO}, \mathrm{O}_{3}, \mathrm{OCS}, \mathrm{CO}_{2}, \mathrm{~N}_{2} \mathrm{O}, \mathrm{CH}_{4}, \mathrm{NO}_{2}, \mathrm{HCl}, \mathrm{C}_{2} \mathrm{H}_{6}, \mathrm{H}_{2} \mathrm{CO}, \ldots\right)$. When locked on the solar disk centre with an accuracy of 4 arcmin by using a photodiode system, the sun-tracker collects the solar radiation after transmission through the atmosphere and transfers it to the lower level experimental room before injecting it into the interferometer. The solar spectra recorded in presence of clouds are excluded. In order to optimize the signal-to-noise ratio and to focus on the species of 
interest, the appropriate optical filters and the detectors combination have to be chosen. In this study, we have used an optical filter from 3.8 to $5.1 \mu \mathrm{m}$ to retrieve especially OCS.

Spectra analyzed for this study were recorded from March 2011 to March 2012 in order to cover a whole year. We have used the PROFFIT algorithm developed by Hase et al. (2004) to retrieve the atmospheric species abundance (Té et al., 2012). PROFFIT is a radiative transfer code based on the Beer-Lambert law for the analysis of solar absorption spectra. The inverse code of PROFFIT supports both Optimal Estimation and Twomey-Tikhonov constraints. The atmosphere is modeled by 49 altitude levels where the a priori volume mixing ratios (vmr) profiles are sampled in parts per million by volume (ppmv) unit (see http://waccm.acd.ucar.edu, Whole Atmosphere Community Climate Model). Pressure and temperature vertical profiles are from NCEP (National Centers Environmental Prediction, see http://www.ncep.noaa.gov) and $\mathrm{H}_{2} \mathrm{O}$ continuum from Clough et al. (2005). HITRAN 2008 database is used for the spectroscopic parameters (position, intensity, pressure line shift and broadening; see Rothman et al. 2009). No change has been noticed for OCS in our micro-windows between the HITRAN 2008 database and HITRAN 2012 (which was released after the submission of the present paper). Four micro-windows (2038.82039.1, 2047.8-2048.7, 2051.2-2051.6 and 2052.5-2057.4 $\mathrm{cm}^{-1}$ ) are selected to retrieve OCS. The interfering species are $\mathrm{H}_{2} \mathrm{O}, \mathrm{CO}_{2}, \mathrm{O}_{3}$ and $\mathrm{CO}$. In this case, solar lines were also taken into account and fitted. The degree of freedom (DOF) is about 1.5 (most of the information are from the troposphere) allowing only retrieval of the total column of OCS. Retrievals can be affected by two kinds of errors: random and systematic. Random errors are the uncertainties in temperature profiles, solar zenith angles (SZA), effects of the instrument noise, and errors in the calculation of the interfering solar lines 
absorption. Systematic errors concern the spectroscopic parameters uncertainty, the $a$ priori profile, and the errors in the instrument line shape function (ILS). Table 1 shows the retrieval errors on the OCS values. The assumptions used in generating the retrieval errors have been more detailed in the paper by Té et al. (2012).

Table 1. OCS retrieved total column uncertainties.

\begin{tabular}{ll}
\hline Error source & OCS error (\%) \\
\hline Temperature & $<0.5$ \\
Instrument noise & $<0.5$ \\
Solar zenith angle & 0.9 \\
Interfering solar lines & $<0.5$ \\
A priori profile & $<0.5$ \\
Instrument line shape & 1 \\
Spectroscopic parameters & 4.5 to 9.5 \\
\hline Total error & 4.7 to 9.7 \\
\hline
\end{tabular}

In conclusion, we have estimated the total error of the OCS retrieval through the PROFFIT algorithm between 4.7\% and 9.7\%. The error bars in Figure 1 and in Table 2 represent the standard deviations of all retrieved columns during one month, without taking into account the retrieval errors. This allows a better assessment of the daily fluctuation during one month.

\section{b Balloon-borne instruments}

This study use data from balloon-borne measurements from three large balloon campaigns. The first was conducted from Teresina $\left(5.1^{\circ} \mathrm{S}, 42.9^{\circ} \mathrm{W}\right)$ in North-East Brazil in June 2008 with a SPIRALE flight on 9 June 2008. The second campaign was conducted from Esrange (Swedish Space Corporation) close to Kiruna $\left(67.9^{\circ} \mathrm{N}-21.1^{\circ} \mathrm{E}\right.$, Sweden). The SWIR-balloon instrument flew on 14 August and SPIRALE on 24 August 2009. The last campaign was also conducted from Esrange, with a SPIRALE instrument flight on 21 April 2011. 
- SWIR-BALLOON INSTRUMENTS

SWIR-balloon (shortwave infrared) is an extended version in the SWIR domain of the IASI-balloon instrument (Té et al., 2002). This instrument is an infrared remote sensing instrument based on a Fourier Transform interferometer. The interferometer uses two InSb detectors to cover both thermal infrared $(3-5 \mu \mathrm{m})$ and SWIR $(1.8-2.4 \mu \mathrm{m})$ domains. In the nadir-looking configuration, the maximum optical path difference (OPD) is fixed at $10 \mathrm{~cm}$. The SWIR-balloon observes the upwelling radiation which is composed of several contributions from the Earth surface emission, the emission and absorption of atmospheric constituents, the emission of the clouds and the reflected solar radiation. Two reference sources on the optical head are used to perform an absolute calibration (Revercomb et al., 1988; Té et al., 2009).

The first flight of SWIR-balloon (SWIR01 flight) took place in polar atmosphere and the instrument was flown around Esrange-Kiruna region (Sweden, $67.9^{\circ} \mathrm{N}, 21.1^{\circ} \mathrm{E}$ ) on 14 August 2009 at 9:26 UT for $5 \mathrm{~h} 58 \mathrm{~min}$. The first position of the gondola at float was $\left[68.1^{\circ} \mathrm{N}, 21.0^{\circ} \mathrm{E}\right]$ and the last position before the balloon cut-off was $\left[68.4^{\circ} \mathrm{N}\right.$, $\left.20.6^{\circ} \mathrm{E}\right]$. The altitude at float varied around $34 \mathrm{~km}$.

The LPMAA Atmospheric Retrieval Algorithm LARA (Té et al., 2002) is a radiative transfer model coupled with an inversion code to retrieve the total columns (from ground to $34 \mathrm{~km}$, the gondola height) of $\mathrm{CO}, \mathrm{O}_{3}, \mathrm{OCS}, \mathrm{CO}_{2}, \mathrm{~N}_{2} \mathrm{O}$ and $\mathrm{H}_{2} \mathrm{O}$. For the OCS retrieval, the spectral window from 2065 to $2145 \mathrm{~cm}^{-1}$ was selected for SWIR01, using the HITRAN 2012 database (Rothman et al., 2013). In addition to OCS, the contribution of six other atmospheric species $\mathrm{H}_{2} \mathrm{O}, \mathrm{CO}_{2}, \mathrm{O}_{3}, \mathrm{~N}_{2} \mathrm{O}, \mathrm{CO}$ and $\mathrm{CH}_{4}$, has been taken into account. The main interfering species in these spectral windows are $\mathrm{H}_{2} \mathrm{O}, \mathrm{CO}_{2}, \mathrm{O}_{3}$ and $\mathrm{CO}$. For the other two constituents, the absorption signals are 
comparable to the noise level. OCS is retrieved from $0.32 \mathrm{~km}$ to $34 \mathrm{~km}$ for SWIR01, using UPMC 2D model (Bekki and Pyle, 1992; Weisenstein and Bekki, 2006) profiles as a vmr profiles. The error bars in Figure 2 are the standard deviations of all retrieved columns during the flight.

- SPIRALE INSTRUMENT

SPIRALE is a spectrometer with six tunable laser diodes for in situ measurements of trace gas species from the upper troposphere to the middle stratosphere ( $\sim 34 \mathrm{~km}$ height). A detailed description of the instrument can be found in a previous paper (Moreau et al., 2005). In brief, six mid-infrared region $(3-8 \mu \mathrm{m})$ laser beams are passed between two mirrors spaced $3.50 \mathrm{~m}$ apart in a Herriott configuration multipass cell located at the extremities of a deployable mast below the gondola, leading to an average path length of $430.5 \mathrm{~m}$. Several species, such as $\mathrm{O}_{3}, \mathrm{~N}_{2} \mathrm{O}, \mathrm{CH}_{4}, \mathrm{HCl}, \mathrm{NO}_{2}$, $\mathrm{HNO}_{3}$ and $\mathrm{CO}$ were measured with high frequency sampling $(\sim 1 \mathrm{~Hz})$, which leads to a vertical resolution of a few meters ( 3 to $5 \mathrm{~m}$ ), depending on the vertical velocity of the balloon. The overall uncertainties take into account the random and systematic errors, combined as the square root of their quadratic sum. The two main sources of random errors are the fluctuations of the laser background emission signal and the signal-tonoise ratio. At low altitudes $(<20 \mathrm{~km})$, the overall uncertainties have the same contribution. Systematic errors originate essentially from the laser line width (an intrinsic characteristic of the laser diode), which contributes more at lower pressure than at higher pressures (lower altitude). For OCS, the overall uncertainty is $3.3 \pm 1.0 \%(1 \sigma$ confidence level) below $18 \mathrm{~km}$, increasing from $10.7 \pm 3.0 \%$ at $18 \mathrm{~km}$ to $30 \%$ at $26 \mathrm{~km}$ and higher than $30 \%$ above $26 \mathrm{~km}$. Absorption micro-windows for the three flights were 
2056.1-2056.5 $\mathrm{cm}^{-1}$, unperturbed by ozone or water absorption. The concentration of OCS was retrieved with the new HITRAN 2012 database (Rothman et al., 2013).

The following time sequences characterized the SPIRALE flights: During the night of 9 to 10 June 2008 in Brazil, the measurements started at 23:30 UT (i.e. 20:30 local time $)$ and the maximum altitude of $33.6 \mathrm{~km}(6.9 \mathrm{hPa})$ was reached at $01: 14 \mathrm{UT}$. The descent phase started at 01:52 UT at $33.7 \mathrm{~km}$ and the measurements ended at 05:35 UT at $16.9 \mathrm{~km}(95 \mathrm{hPa})$.For the second flight on the night of 24 to 25 August 2009 in Sweden, the measurements started at 20:50 UT (i.e. 23:50 local time) and the maximum altitude of $34.1 \mathrm{~km}(6.9 \mathrm{hPa})$ was reached at 22:30 UT. The descent phase started at 23:26 UT at $33.7 \mathrm{~km}$ and the measurements ended at 01:36 UT at $16.7 \mathrm{~km}(94 \mathrm{hPa})$. The third flight on 20 April 2011 in Sweden again is characterized by a slow ascent with measurements starting at 21:00 UT at $8.6 \mathrm{~km}$ to $23: 30 \mathrm{UT}$ at $33.3 \mathrm{~km}$.

\section{Results and discussion}

a Column variability

- SEASONAL VARIABILITY ABOVE PARIS

Figure 1 presents the monthly mean OCS total column in Paris and the tropospheric OCS vmr averaged from March 2011 to March 2012 measured by QualAir FTS. Table 2 presents the values and the errors corresponding to the standard deviation used to make Figure 1. Seasonal patterns appear in the OCS data with a maximum in April-June $\left(10.9 \times 10^{15}\right.$ molecules $\mathrm{cm}^{-2}$ and $\left.544 \mathrm{pptv}\right)$ and a minimum in NovemberJanuary $\left(9.8 \times 10^{15}\right.$ molecules $\mathrm{cm}^{-2}$ and $\left.507 \mathrm{pptv}\right)$. OCS variability with season is equal to $10 \%$ (peak to peak variation). The annual variation and the period of maximum observed are consistent with the study of Lejeune et al. (2011) at Jungfraujoch (NDACC 
station, $\left.46.6^{\circ} \mathrm{N}\right)$. However, these authors observed a minimum during OctoberDecember with a peak to peak variation of $7.9 \%$ whereas we found a minimum shifted to November-January. Similar periods are observed at Izana $\left(28.30^{\circ} \mathrm{N}, \mathrm{NDACC}\right.$ station) as reported by Notholt and Bingemer (2006) with a minimum in October-December and an annual variation of $10 \%$. However a minimum during November-January period, as in our work, is observed at Kitt Peak $\left(32^{\circ} \mathrm{N}\right)$ (Rinsland et al., 2002). To sum up, a strong seasonal variation exists for many ground-based sites in the Northern hemisphere, with a minimum between October and January and a maximum between April and June (Notholt and Bingemer, 2006).

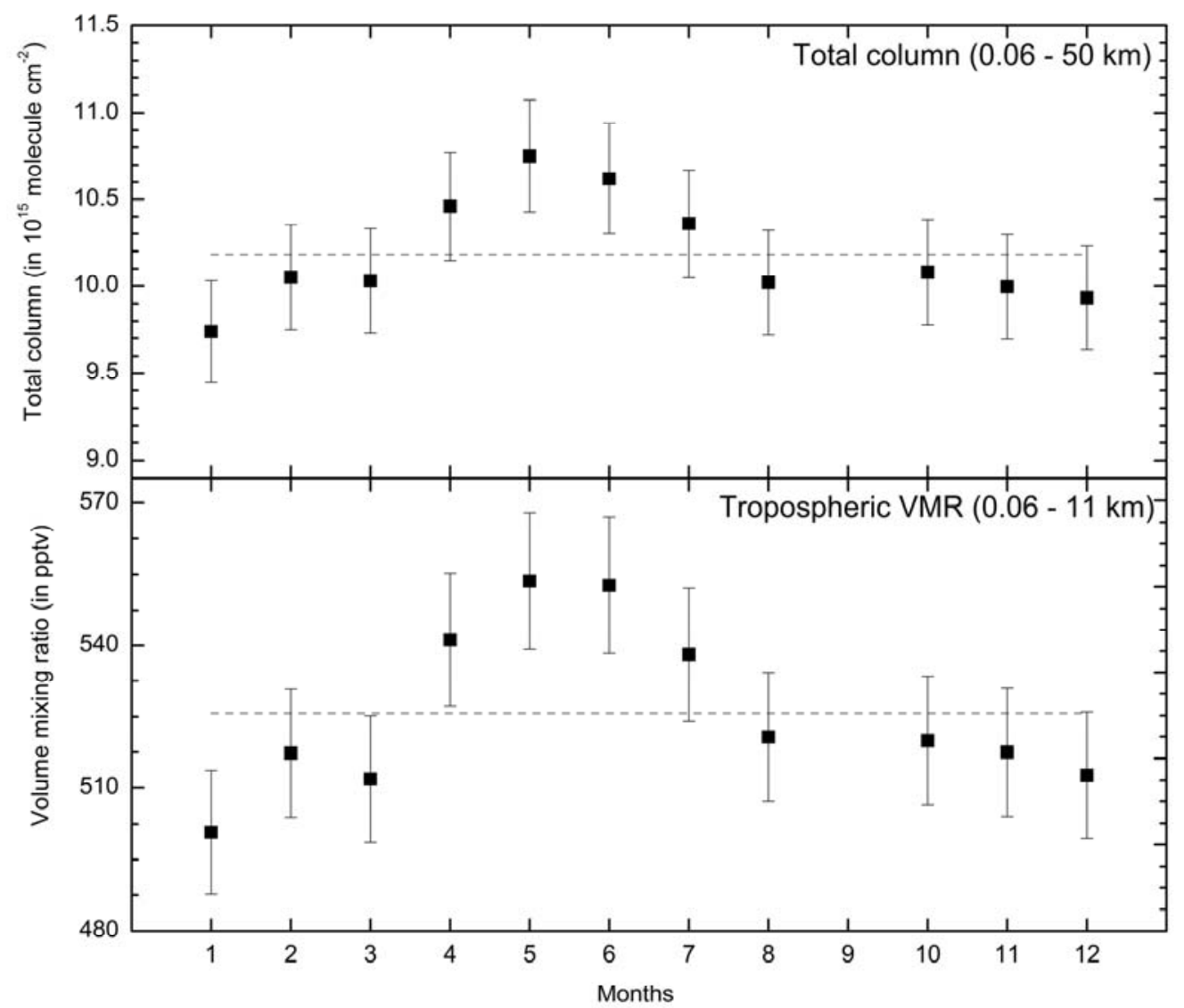

Figure 1. Average OCS total column and volume mixing ratio (vmr) with error bars (1 standard deviation $\sigma$ ) above Paris measured by FTIR from March 2011 to March 2012. The grey dashed lines represent the annual weighted averages (the weight of each measurement is relative to its standard deviation). 
Table 2. Monthly averaged OCS total column and volume mixing ratio, with their errors, above Paris measured by QualAir FTS (described in Section 2a) from March 2011 to March 2012.

\begin{tabular}{ccccc}
\hline Months & $\begin{array}{c}\text { Total column } \\
\left(\times 10^{15} \text { molecules } \mathrm{cm}^{-2}\right)\end{array}$ & $\begin{array}{c}\text { Error }(1 \sigma) \text { on column } \\
\left(\times 10^{15} \text { molecules } \mathrm{cm}^{-2}\right)\end{array}$ & $\begin{array}{c}\text { Tropospheric } \\
\text { vmr } \\
(\mathrm{pptv})\end{array}$ & $\begin{array}{c}\text { Error on } \\
\text { tropospheric } \\
\text { vmr }(\mathrm{pptv})\end{array}$ \\
\hline January & 9.74 & 0.29 & 500.7 & 13.0 \\
February & 10.05 & 0.30 & 517.3 & 13.4 \\
March & 10.03 & 0.30 & 511.9 & 13.3 \\
April & 10.46 & 0.31 & 541.2 & 14.0 \\
May & 10.75 & 0.32 & 553.6 & 14.3 \\
June & 10.62 & 0.32 & 552.7 & 14.3 \\
July & 10.36 & 0.31 & 538.1 & 13.9 \\
August & 10.02 & 0.30 & 520.7 & 13.5 \\
September & -- & -- & -- & -- \\
October & 10.08 & 0.30 & 519.9 & 13.5 \\
November & 10.00 & 0.30 & 517.5 & 13.4 \\
December & 9.93 & 0.30 & 512.7 & 13.3 \\
\hline
\end{tabular}

${ }^{1}$ For September, only one day measurements is available, which is not representative of monthly averaging.

The seasonal variations are directly related to the natural sinks and sources of OCS (Kettle et al., 2002a). The amplitude of the variation depends on surface processes such as the imbalance between vegetation and soil uptakes and oceanic fluxes. The maximum in the total column occurs during the highest production of OCS (direct flux), DMS and $\mathrm{CS}_{2}$ (indirect flux) by biogenic processes in the ocean during late spring and the beginning of summer (Kettle et al., 2002a) and just before the maximum of OCS uptake by land plants during July-September (Kettle et al., 2002b). The minimum period in October-January occurs during the lowest production by oceans and during less stronger but still significant uptake by plants, soils and $\mathrm{OH}$ reaction (Kettle et al., 2002a).

- LATITUDINAL VARIABILITY

An update of the long-term OCS total column shows an annual increase lower than $0.79 \%$ (Montzka and Reimann, WMO 2011). Consequently, for the rest of this study, we assume a negligible inter-annual variation and can compare measurements 
from different years. OCS total columns are extracted from SWIR-balloon measurements at Esrange and from QualAir FTS Paris station measurements. These total columns are compared with other weighted average measurements (the weight of each measurement is relative to its standard deviation) OCS total column from NDACC stations (http://www.ndsc.ncep.noaa.gov/), from Polarstern cruise campaigns well referenced (Notholt et al., 2000; Xu et al., 2001) and from other campaigns of the MkIV instrument at different latitudes.

Most of the measurements used for this study come from instruments using FTIR to detect OCS, and mostly in the same domain of wavelengths $\left(2040 \mathrm{~cm}^{-1}\right.$ and $\left.2080 \mathrm{~cm}^{-1}\right)$. A total of 19 stations of measurements are used with 11 datasets coming from the MkIV instrument (Toon et al. 1991). MkIV uses the bands between 2041 and $2077 \mathrm{~cm}^{-1}$ to detect OCS in the atmosphere. The other stations measurements use the same approach to derive OCS. All the dataset coming from MkIV use the new HITRAN database updated in 2012 (Rothman et al., 2013). For the other stations utilizing the HITRAN spectroscopic parameters before 2008, the columns were multiplied by 0.86 , corresponding to the increase in the line strengths of OCS. All comparisons are shown in Figure 2. The Figure is divided into four plots according to the seasonal variation found in Section 3a (Seasonal variability): January/February/March (JFM), April/May/June (AMJ), July/August/September (JAS) and October/November/December (OND). The total columns of OCS plotted in Figure 2 are scaled to sea level by multiplying the total column by the ratio between the standard pressure $(1013 \mathrm{hPa})$ and the surface pressure observed in each station. 
Figure 2. Pressure corrected total column of OCS with error bars (standard deviation) versus latitude $\left({ }^{\circ} \mathrm{N}\right)$. The ground based (NDACC and other) and balloon-borne measurements from the Bruker IFS125HR interferometer, from the MkIV instrument (in orange, Toon et al. 1991) and from the QualAir FTS instrument (in red) are weighted average of several years with minimum and maximum of each range shown by crosses and dashed lines. The other measurements are from Polarstern cruise campaigns measured by Bruker 120M interferometer (Notholt et al., 2000; $\mathrm{Xu}$ et al., 2001) and from the SWIR-balloon instrument from the Esrange balloon campaign (in red, Té et al., 2002). 
A latitudinal trend seems to appear in the OCS total columns whatever the season. OCS total column decreases from tropical to polar latitudes, from $(10-11) \times 10^{15}$ molecules $\mathrm{cm}^{-2}$ to $(6.5-9) \times 10^{15}$ molecules $\mathrm{cm}^{-2}$. SWIR measurements from Esrange and QualAir FTS measurement (in red symbols in Figure 2) are in accordance with the latitudinal trend observed within the uncertainties. Polarstern cruise campaigns highlight a maximum in the values near $20^{\circ} \mathrm{N}$ of latitude in the Atlantic Ocean $\left(17^{\circ} \mathrm{N}-21^{\circ} \mathrm{W}\right.$ for JFM months and $23^{\circ} \mathrm{N}-30^{\circ} \mathrm{W}$ for OND). Bates et al. (1992) show maximum oceanic sulfur emissions in latitude between $5^{\circ} \mathrm{N}-20^{\circ} \mathrm{N}$. In addition, over the Atlantic Ocean, the atmosphere is clearly affected by the African and South American biomass burning leading to OCS emission (Junkermann and Stockwell, 1999).

The high latitude part seems to be more affected by seasonal variations. While a seasonal variation of $14 \%$ is observed at Thule $\left(76.53^{\circ} \mathrm{N}\right)$, a mean value of $10.5 \times 10^{15}$ molecules $\mathrm{cm}^{-2}$ without any significant variation for the six months of measurements (JFM and OND) is measured for latitudes between $20^{\circ} \mathrm{S}$ and $20^{\circ} \mathrm{N}$. A minimum of $6.61 \times 10^{15}$ molecules $\mathrm{cm}^{-2}$ is observed at Thule during OND compared to the maximum value during AMJ of $7.58 \times 10^{15}$ molecules $\mathrm{cm}^{-2}$. Barkley et al. (2008) observed the same phenomena in the OCS vertical profile from ACE for different seasons with the tropical latitude $\left(20^{\circ} \mathrm{S}-20^{\circ} \mathrm{N}\right)$ with OCS values remaining rather constant over the year.

OCS has a long lifetime, resulting in a quasi-uniformity of its vmr in the troposphere. However, is the tendency in the total column also observed in the partial column above $13 \mathrm{~km}$ ? Figure 3 shows the OCS partial column in the upper troposphere and lower stratosphere (UTLS) (above $13 \mathrm{~km}$ ) for the balloon campaigns of SWIRballoon instrument at Esrange compared with balloon campaigns of the MkIV instrument (SOLVE I and II, STRAT and POLARIS, http://espoarchive.nasa.gov/) and 
several aircraft campaigns where OCS is measured by FTIR (P-AVE, Coffey and Hannigan, 2010) AASE II; http://espoarchive.nasa.gov/). All these datasets use the HITRAN 2008 or 2012 databases. The SOLVE I and II, P-AVE and AASE II occurred in December and JFM months and are represented in black in Figure 3 and the POLARIS, STRAT, StraPolEte campaigns in June and JAS months and are represented in blue. As for total column, a trend of the OCS column with the latitude appears for altitudes above $13 \mathrm{~km}$, from $0.5 \times 10^{15}$ molecules $\mathrm{cm}^{-2}$ at the polar latitudes to $2.0 \times 10^{15}$ molecules $\mathrm{cm}^{-2}$. This trend observed also in the stratosphere shows that the tropical UTLS is composed of tropospheric young air transported from local source compared to the polar stratosphere composed of aged air coming mainly from tropical stratosphere. As previously for total column in the tropics, a maximum value is found at $17^{\circ} \mathrm{N}$ of latitude in the Atlantic Ocean $\left(17^{\circ} \mathrm{N}-66^{\circ} \mathrm{W}\right.$, Near Dominican Republic). Again, this is both due to the high oceanic emissions found at these latitudes $\left(5^{\circ} \mathrm{N}-20^{\circ} \mathrm{N}\right)$ and transported by convection and to the African biomass burning transported over the Atlantic Ocean (Ricaud et al., 2007). 


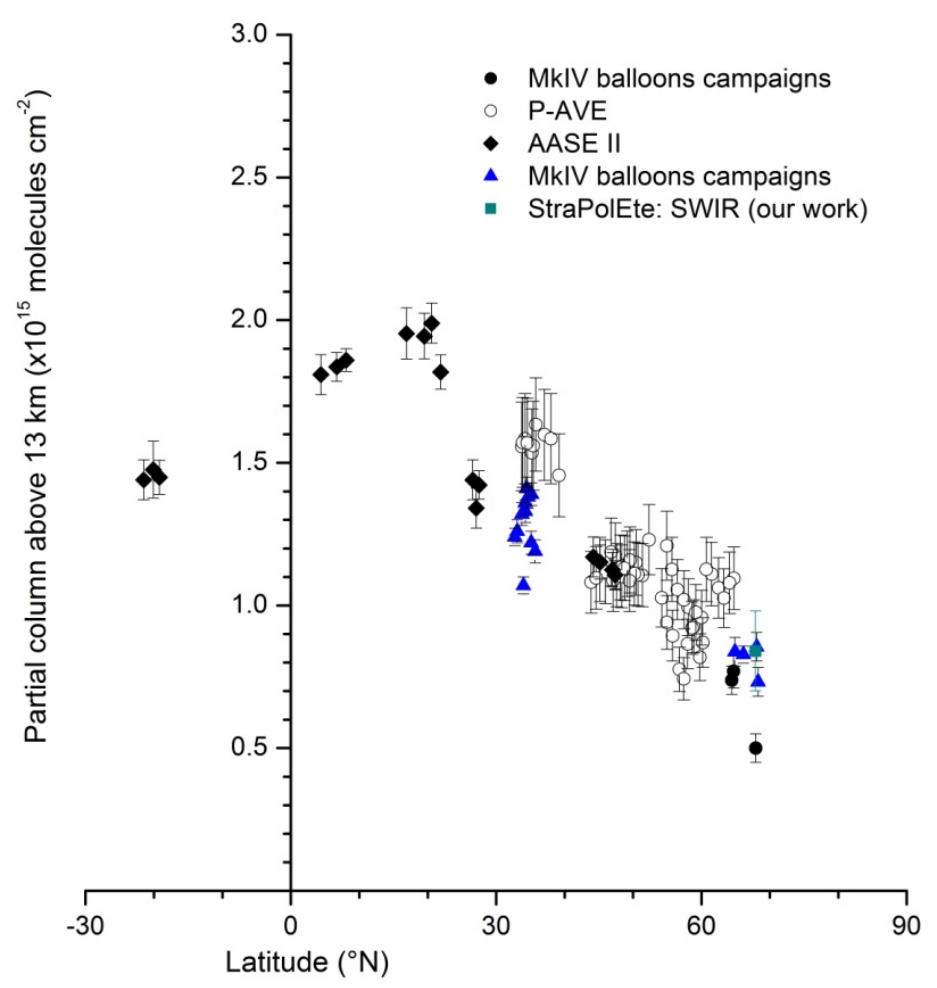

Figure 3. OCS partial column above $13 \mathrm{~km}$ with error bars (representing the 1- $\sigma$ measurement precisions) versus latitude $\left(\mathrm{N}^{\circ}\right)$ from several MkIV campaign (STRAT, POLARIS, SOLVE I and II and AASE II) (Toon et al. 1991,1993), aircraft P-AVE campaigns measured by FTIR instrument (Coffey and Hannigan, 2010) and from StraPolEte balloon campaign measured by the SWIR instrument (in dark cyan) (Té et al., 2002). The values in blue (blue and dark cyan) are for campaigns occurring during June, July and August and in black for campaigns occurring during January, February and March.

\section{$b \quad$ Vertical in situ measurements}

- VERTICAL VARIABILITY WITH LATITUDE

Figure 4 shows for the first time high resolution in situ OCS measurements at two different latitudes (tropical $\left(5.1^{\circ} \mathrm{S}\right)$ and polar $\left.\left(67.9^{\circ} \mathrm{N}\right)\right)$, measured by the SPIRALE instrument. These profiles correspond to the flights on 9 June 2008 at Teresina, and on 24 August 2009 and on 20 April 2011 at Esrange. The thermal tropopauses (WMO, 1957) were located at $16.9 \mathrm{~km}, 9.5 \mathrm{~km}$ and $9.3 \mathrm{~km}$ height on 9 June 2008, 24 August 
2009 and 21 April 2011, respectively. Consequently, only the vertical profile at tropical latitude contains values in the upper troposphere, and in particular in the tropical tropopause layer (TTL) (Fueglistaler et al., 2009). The altitude of the TTL for the SPIRALE flight identified by blue line in Figure 4 is 14.4 km - 18.0 km (Marécal et al., 2011). The transition from the TTL to the stratosphere is clearly seen by a decrease of the OCS vmr from more than $550 \mathrm{ppt}$ to less than $500 \mathrm{ppt}$. The TTL is characterized by the transition from a pure tropospheric regime to a pure stratospheric regime. The bottom of the TTL is directly affected by the main convective outflow and consequently the OCS vmr is almost constant, with values comparable to those found in the troposphere. The upper TTL is not affected by convection and consequently OCS sinks (photolysis, $\mathrm{OH}$ reaction) are predominant.

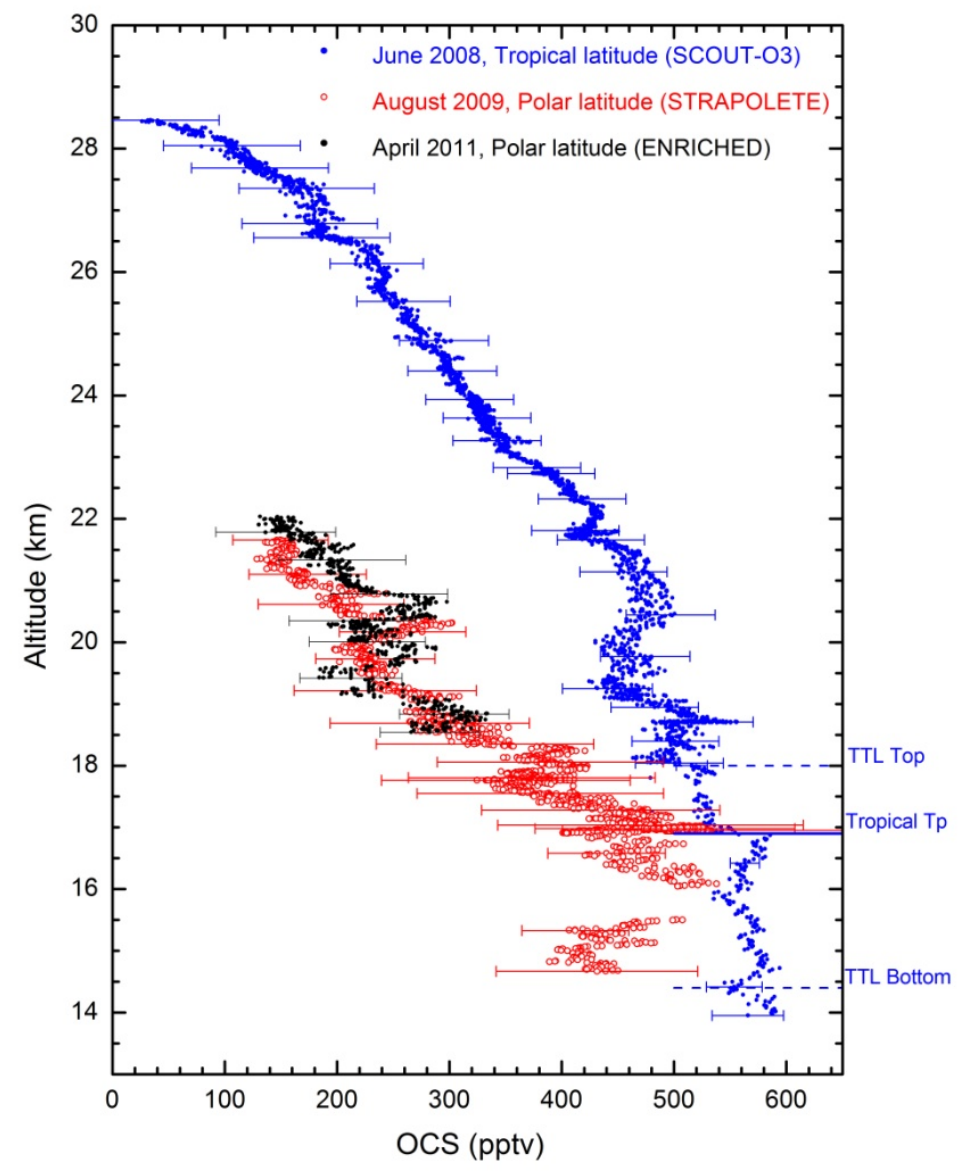


Figure 4. SPIRALE measurements of OCS volume mixing ratios (in ppt) with error bars on 9 June 2008 (blue full circles) above Teresina $\left(5.1^{\circ} \mathrm{S}-42.9^{\circ} \mathrm{W}\right.$, Brazil), on 24 August 2009 (red open circles) and 20 April 2011 (black full circles) above Esrange (67.9 $\mathrm{N}-21.1^{\circ} \mathrm{E}$, Sweden). The Thermal Tropopause (Tp) and the tropical tropopause layer (TTL) top and bottom are represented by blue line and blue dashed lines respectively for the flight at tropical latitude on June 2008.

The OCS vertical distribution is well shown by the profiles. OCS mixing ratios at the tropical latitude are approximately constant between 14 and $17 \mathrm{~km}$ altitude with values of 540-570 pptv and then start to decrease above the thermal tropopause (Tp) from 550 pptv at $17 \mathrm{~km}$ height to $34 \mathrm{pptv}$ at $28.5 \mathrm{~km}$ height. Indeed, OCS is destroyed in the stratosphere mainly by photolysis (Notholt and Bingemer, 2006) with a maximum absorption for $\lambda<250 \mathrm{~nm}$ (Molina et al., 1981). According to DeMore et al. (1997), for $\lambda<250 \mathrm{~nm}$, the actinic flux is maximum for altitudes higher than $20 \mathrm{~km}$. The OCS mixing ratio behavior at polar latitudes is similar to that at tropical latitude. Due to instrumental problems, the polar profile is more scattered than the tropical one. We observe for polar latitude a decrease of OCS vmr with altitude, from $420 \pm 100$ pptv for altitudes lower than $17 \mathrm{~km}$ and then a decrease from 460 pptv to $150 \mathrm{pptv}$ at $22 \mathrm{~km}$. During the STRAT campaign in July 1996, the MkIV instrument observed similar behaviors with OCS constant vmr values of 440 pptv below $14 \mathrm{~km}$ (Leung et al., 2002) and then a decrease to $120 \mathrm{pptv}$ at $22 \mathrm{~km}$.

The latitudinal variation of OCS in the stratosphere is significant, with a large vmr difference increasing from about 150 pptv to about 300 pptv between the tropopause and $22 \mathrm{~km}$. Barkley et al. (2008) with the OCS ACE satellite data observed a similar difference in OCS vmr, of about $250 \mathrm{pptv}$, between the tropical and polar latitudes. This phenomenon is also observed in the OCS partial column explained in the Section 3a (Latitudinal variability). This is due to the global atmospheric transport 
regulating the OCS polar stratospheric amount. OCS tropospheric air reaches the stratosphere at tropical latitude. Subsequently, OCS is transported poleward by the Brewer-Dobson circulation while being photodissociated. Tropical and midlatitude poleward intrusions of tropospheric air into the extratropical stratosphere are also possible stratospheric sources of OCS (Roiger et al., 2011; Krysztofiak et al., 2012) which possibly explain the various OCS vmr enhancements on the polar profiles.

- COMPARISONS WITH ACE SATELLITE DATA

The Atmospheric Chemistry Experiment (ACE) on board the Canadian SCISAT satellite (Bernath et al., 2005) was launched on 12 August 2003. Using the solar occultation technique, two instruments measure the vertical profiles of atmospheric constituents from the troposphere to the lower mesosphere. For this study, we use the OCS version 3.0 (v.3.0) of the vmr profiles from the instrument ACE Fourier Transform Spectrometer (ACE-FTS). A total of thirteen microwindows are used for the OCS ACEFTS v. $3.0 \mathrm{vmr}$ retrievals, positioned at $1950.10 \mathrm{~cm}^{-1}$ for the first one, and between $2039.01 \mathrm{~cm}^{-1}$ and $2057.52 \mathrm{~cm}^{-1}$ for the other ones. In order to compare ACE-FTS and SPIRALE we must take into account the difference in the vertical resolution of these two instruments. Indeed, ACE-FTS has a vertical resolution of 2-6 $\mathrm{km}$ and that of SPIRALE is of a few meters. For comparisons, we use the ACE-FTS retrieved results which are interpolated onto a $1 \mathrm{~km}$ grid from $0.5 \mathrm{~km}$ to $149.5 \mathrm{~km}$. A weighting triangular function of $3 \mathrm{~km}$ at the base has been applied to SPIRALE data interpolated first onto a $5 \mathrm{~m}$ grid. Consequently, we have truncated the bottom and the top of SPIRALE profile from $1.5 \mathrm{~km}$.

As explained in Section 3a (Latitudinal variability), we assume a negligible OCS variation between 2003 (start date of ACE measurements) and the year of our SPIRALE 
balloon flights (i.e. 2008 and 2009). Moreover, as seen in Section 3a (Seasonal variability), there is a seasonal trend in the OCS vmr. Consequently, for ACE-FTS comparisons with SPIRALE at Teresina on June 2008, we use OCS profiles from April to June and for comparisons at Esrange in August 2009, we use OCS profiles from July to September and only the profiles above land (balloon flights occurred above land). There are not a lot of ACE profiles available at tropical latitudes thus for the comparison at Teresina, we used 6 profiles (between 2004 and 2007) acquired at $5 \pm 6^{\circ} \mathrm{S}$ and $43[+20,-10]^{\circ} \mathrm{W}$. For the comparison at Kiruna, we used 56 profiles (between 2004 and 2011) acquired at $67.9 \pm 6^{\circ} \mathrm{N}$ and $21.1 \pm 10^{\circ} \mathrm{E}$.

Figure 5 (left) shows the comparisons between SPIRALE OCS measurements and the weighted average (weight of each measurement relative to its standard deviation) of the ACE-FTS OCS profiles. Figure 5 (right) shows the difference between SPIRALE and ACE average (SPIRALE - ACE \%) compared to the mean value and the error bars.

At tropical latitudes, for altitudes lower than $22.5 \mathrm{~km}$, ACE-FTS underestimates OCS values compared to SPIRALE. The differences between SPIRALE and ACE indicate a bias between $15 \%$ and 20\%. For altitudes higher than $22.5 \mathrm{~km}$ at Teresina, SPIRALE and ACE-FTS are in very good agreement (within 10\%).

For polar latitudes, at Esrange, SPIRALE and ACE-FTS are also in very good agreement (within 11\%) by taking into account the uncertainties of both instruments except at the altitude of $16.5 \mathrm{~km}$ where ACE-FTS underestimates OCS values compared to SPIRALE with a bias of $20 \%$.

Velazco et al. (2011, Figure 18) show similar bias of 15\% between ACE-FTS and MkIV OCS profiles for altitudes between $12 \mathrm{~km}$ and $23 \mathrm{~km}(350-550 \mathrm{~K})$ at $35^{\circ} \mathrm{N}$ of latitude. 

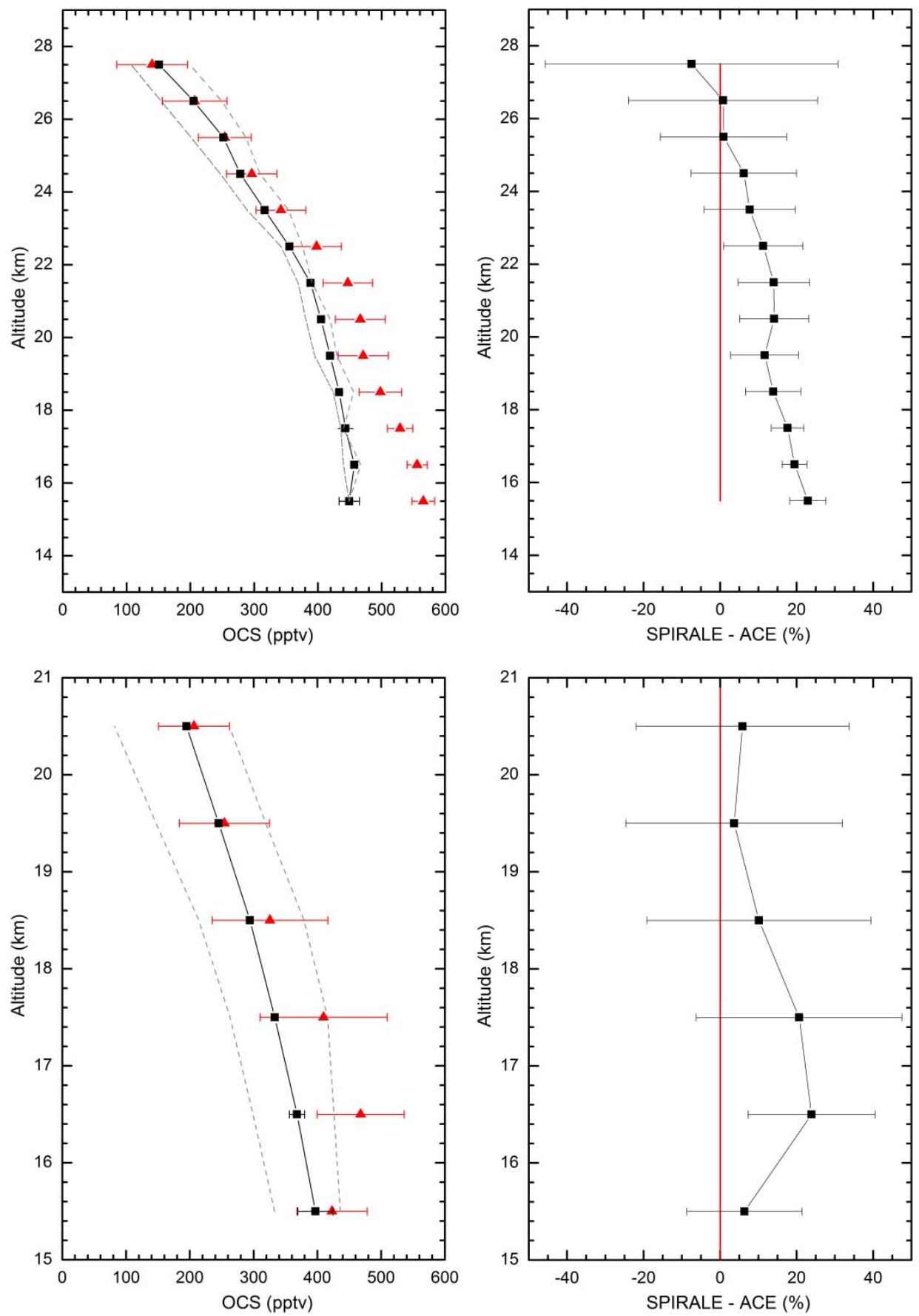

Figure 5. Left panels: SPIRALE measurements of OCS volume mixing ratios (in pptv) with error bars (red triangles) compared to the weighted average (weight of each measurement relative to its $1-\sigma$ error) of the ACE-FTS OCS profiles with error bars (1- $\sigma)$ (black squares). The grey dashed lines represent the spread (minimum and maximum values found in all the ACE profiles). Right panels: percentage differences between SPIRALE and ACE-FTS with error bars. Top panels: Comparisons for SPIRALE flight on 9 June 2008 at Teresina (Brazil) and Bottom panels: Comparisons for SPIRALE flight on 24 August 2009 at Esrange (Sweden). 
- STRATOSPHERIC LIFETIME

Plumb and Ko (1992) highlighted the use of tracer-tracer correlations to determine the atmospheric lifetime of species. Simultaneous $\mathrm{N}_{2} \mathrm{O}$ measurements were performed by SPIRALE in the tropical and polar regions. As OCS, $\mathrm{N}_{2} \mathrm{O}$ has purely tropospheric sources (Seinfeld and Pandis, 2006) and possess a long lifetime compared to horizontal and vertical air motions. The lower stratosphere (below $22 \mathrm{~km}$ ) correlation between OCS and $\mathrm{N}_{2} \mathrm{O}$ is linear and the relationship between their atmospheric lifetimes is represented by this equation:

$$
\tau_{\mathrm{OCS}} / \tau_{\mathrm{N}_{2} \mathrm{O}}=A \times v m r_{\mathrm{OCS}} / v m r_{\mathrm{N}_{2} \mathrm{O}}
$$

Where $\tau$ represents the stratospheric lifetime, vmr the tropospheric volume mixing ratio, $A$ the slope of the correlation (Plumb and Ko, 1992).

Due to the absence of data below $18 \mathrm{~km}$ in the OCS profile at the polar latitude on 21 April 2011, the lower stratosphere correlation between OCS and $\mathrm{N}_{2} \mathrm{O}$ cannot be plotted and no lifetime has been calculated for this date.

Figure 6.A represents the $\mathrm{N}_{2} \mathrm{O}$ :OCS correlation in the lower stratosphere at the tropical latitude in 2008 and Figure 6.B at the polar latitude in 2009 from SPIRALE measurements. Both linear correlations lead to an $\mathrm{r}^{2}$ correlation coefficient higher than 0.75 .

We use $\mathrm{N}_{2} \mathrm{O}$ lifetime from Montzka and Fraser et al. (2003) of $117 \pm 20$ years and a mean tropospheric mixing ratio of $328 \pm 8$ ppbv $\mathrm{N}_{2} \mathrm{O}$ and $550 \pm 40$ pptv OCS from SPIRALE measurements to calculate the OCS stratospheric lifetime at tropical and polar latitudes. We find a lifetime of $70 \pm 20$ years for the polar latitude case and $58 \pm 14$ years for the tropical latitude case, which leads to a mean global stratospheric lifetime of $64 \pm 17$ years. Actinic fluxes for $\lambda<250 \mathrm{~nm}$ (OCS photodissociation) and for altitudes higher than $20 \mathrm{~km}$ show a difference with latitude (Finlayson-Pitts and Pitts, 2000). 
Indeed, for the same solar time and months (here June and August), the solar zenith angle is smaller at tropical latitudes compared to polar latitudes and for $\lambda<250 \mathrm{~nm}$ the actinic fluxes increase with decreasing solar zenith angles. Consequently, OCS undergoes stronger photolysis at tropical latitudes and has a lower stratospheric lifetime.
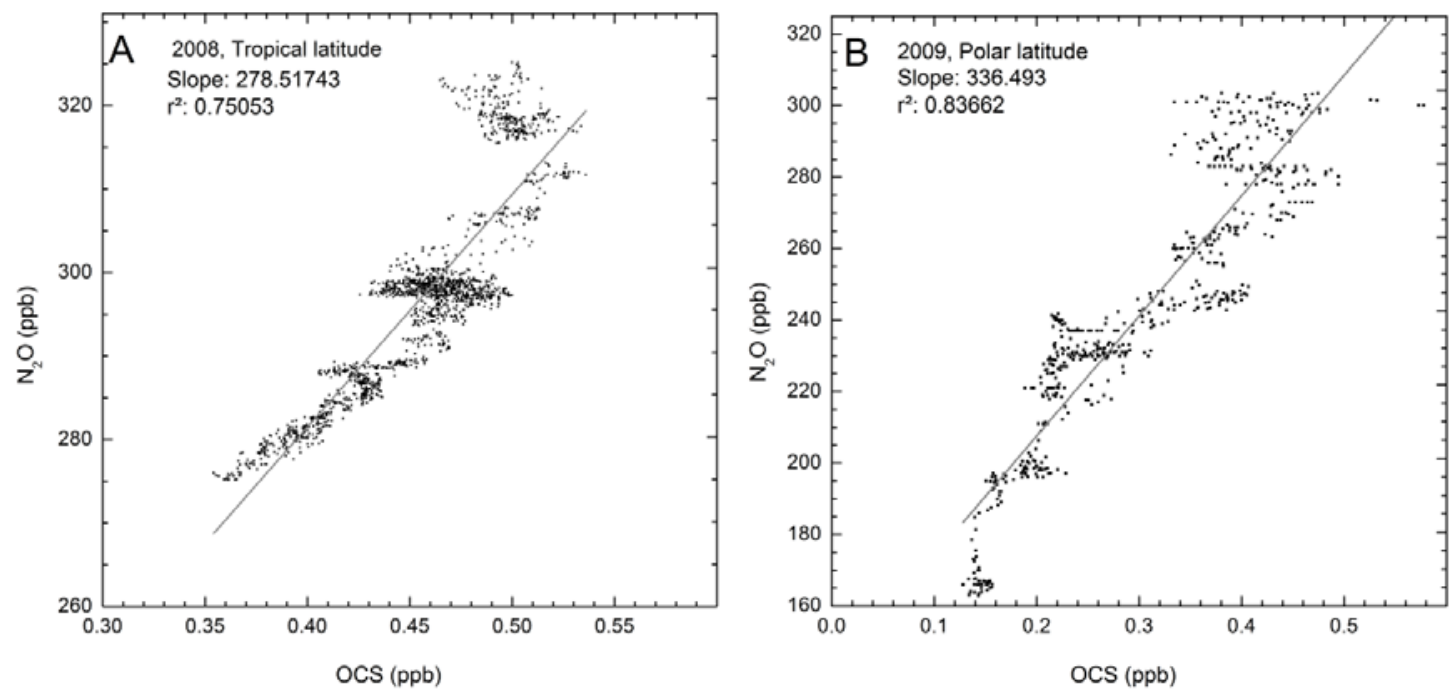

Figure 6. Correlation between $\mathrm{N}_{2} \mathrm{O}$ and OCS from SPIRALE volume mixing ratio in situ measurements in the lower stratosphere (below $22 \mathrm{~km}$ ), A: on 9 June 2008 above Teresina $\left(5.1^{\circ} \mathrm{S}-42.9^{\circ} \mathrm{W}\right.$, Brazil) and B: on 24 August 2009 above Esrange $\left(67.9^{\circ} \mathrm{N}-21.1^{\circ} \mathrm{E}\right.$, Sweden).

Using the correlation with $\mathrm{CFCl}_{3}$ (lifetime of 55 years), Engel and Schmidt (1994) found an OCS stratospheric lifetime of $69 \pm 28$ years for latitudes higher than $43^{\circ} \mathrm{N}$ from measurements at Kiruna $\left(68^{\circ} \mathrm{N}\right)$ and Aire sur $1^{\prime}$ Adour $\left(43^{\circ} \mathrm{N}\right)$. Using correlations with $\mathrm{CF}_{2} \mathrm{Cl}_{2}$ and $\mathrm{CFCl}_{3}$, Barkley et al. (2008) found a global OCS stratospheric lifetime of $64 \pm 21$ years. These values are consistent with our global value. The value found by Engel and Schmidt (1994) is consistent with our polar value. Unfortunately, Barkley et al. (2008) did not estimate OCS lifetime at latitudes between $20^{\circ} \mathrm{N}$ and $20^{\circ} \mathrm{S}$, and so no comparison is possible with our OCS lifetime found at tropical latitude (Teresina). 
The correlations between $\mathrm{N}_{2} \mathrm{O}$ and OCS from the data of ACE-FTS used in the section 3.b (Comparisons with ace satellite data) in polar region and from the MkIV measurements during several campaigns (SOLVE I and II) in the Kiruna region are used to extract the OCS lifetime in polar region. These results are compared with our lifetime from SPIRALE measurements in polar region and the other lifetime found by the studies of Engel and Schmidt (1994) and by Barkley et al. (2008) only at polar latitude. Table 3 shows these comparisons. All the lifetimes found in the polar region are consistent each other and allows us to establish an OCS lifetime by taking into account the overall uncertainties in polar region of $71 \pm 10$ years $(1 \sigma)$.

Table 3. OCS lifetimes (years) in polar region found from SPIRALE measurements, from ACEFTS measurements (data from the section3.b (Comparisons with ace satellite data)) and from MkIV measurements (G. Toon and http://mark4sun.jpl.nasa.gov/m4data.html) compared with the study of Engel and Schmidt (1994) and Barkley et al. (2008).

\begin{tabular}{lccccc}
\hline & $\begin{array}{c}\text { Engel and } \\
\text { Schmidt } \\
(1994)\end{array}$ & $\begin{array}{c}\text { Barkley et al. } \\
(2008)\end{array}$ & ACE-FTS & MkIV & SPIRALE \\
\hline Lifetime (Years) & $69 \pm 28^{1}$ & $76 \pm 32^{1}$ & $70 \pm 16^{2}$ & $74 \pm 24^{2}$ & $\mathbf{7 0 \pm 2 0}{ }^{2}$ \\
\hline
\end{tabular}

${ }^{1}$ CFC-12/OCS correlation

${ }^{2} \mathrm{~N}_{2} \mathrm{O} / \mathrm{OCS}$ correlation

We can calculate the stratospheric OCS sink by dividing the total OCS mass in the atmosphere, $5.86 \times 10^{12} \mathrm{~g}$ (inferred from the total atmospheric mass of $5.148 \times 10^{21} \mathrm{~g}$ (Trenberth and Smith, 2005) and our tropospheric OCS vmr) by our global OCS lifetime. We find a global stratospheric sink of $99 \pm 26 \mathrm{Gg}$ OCS $\mathrm{yr}^{-1}$, corresponding to $54 \pm 14 \mathrm{Gg} \mathrm{S} \mathrm{yr}^{-1}$. Table 4 shows a comparison between our values of OCS stratospheric sink and several values from literatures. Our range values are in general accordance with the average $50 \pm 15(1 \sigma) \mathrm{Gg} \mathrm{S} \mathrm{yr}^{-1}$ of the OCS stratospheric sinks given by previous studies. 
Table 4. OCS stratospheric sink (Gg S yr-1) comparison with previous studies

\begin{tabular}{|c|c|c|c|c|c|c|c|c|}
\hline & $\begin{array}{l}\text { Crutzen } \\
(1976)\end{array}$ & $\begin{array}{l}\text { Turco et } \\
\text { al. } \\
(1980)\end{array}$ & $\begin{array}{l}\text { Crutzen et } \\
\text { Schmailzl } \\
(1983)\end{array}$ & $\begin{array}{l}\text { Engel et } \\
\text { Schmidt } \\
(1994)\end{array}$ & $\begin{array}{l}\text { Chin et } \\
\text { Davis } \\
(1995)\end{array}$ & $\begin{array}{l}\text { Weisenstein } \\
\text { et al. (1997) }\end{array}$ & $\begin{array}{l}\text { Barkley } \\
\text { et al. } \\
(2008)\end{array}$ & $\begin{array}{l}\text { This } \\
\text { work }\end{array}$ \\
\hline OCS & & & & & & & & \\
\hline $\begin{array}{l}\text { Stratospheric } \\
\text { sink } \\
\left(\mathrm{Gg} \mathrm{S} \mathrm{an}^{-1}\right)\end{array}$ & 50 & 80 & 43 & $49 \pm 20$ & 30 & 49 & $50 \pm 16$ & $54 \pm 14$ \\
\hline
\end{tabular}

\section{Conclusions and perspectives}

Carbonyl sulfide (OCS) is the most abundant sulfur-containing compound in the atmosphere. Due to its long lifetime, OCS can easily reach the stratosphere and is, with $\mathrm{SO}_{2}$, the precursor of sulfate aerosols. Consequently, it is a key species for understanding heterogeneous chemistry of stratospheric ozone depletion.

A seasonal variation is extracted from the ground-based FTS measurements of the QualAir (Qualité de l'Air) platform at Jussieu campus in Paris. A maximum value of the total column and the tropospheric mean vmr are found in April-June and a minimum value in November-January with a peak to peak variability of $10 \%$.

Total column measurements from QualAir FTS measurements above Paris and SWIR balloon-borne instruments are compared with several MkIV measurements, NDACC stations measurements, ship measurements and balloon-borne measurements, to highlight the OCS variability with latitude. OCS total column decreases with increasing latitude. The variability is also found for the partial column above $13 \mathrm{~km}$ showing the atmospheric OCS transport from the tropical troposphere into the tropical stratosphere and then into the polar stratosphere. The OCS total columns show a seasonal variability more pronounced at polar latitudes compared to tropical latitudes.

The first high resolution vertical profile of OCS at two different latitudes is presented in this paper. The SPIRALE balloon-borne instrument has flown over the tropical region $\left(5.1^{\circ} \mathrm{S}\right.$, Teresina, Brazil) on 9 June 2008 and over the Arctic polar region 
$\left(67.9^{\circ} \mathrm{N}\right.$, Esrange, Sweden) on 24 August 2009. The OCS vertical dependence is similar for both latitudes with a significant decrease in OCS vmr above $20 \mathrm{~km}$. OCS profiles are also compared with non-coincident ACE satellite measurements and show consistency for the polar latitude case and a bias of $15-20 \%$ for the tropical latitude case for altitudes lower than $22 \mathrm{~km}$.

Using OCS: $\mathrm{N}_{2} \mathrm{O}$ correlation from SPIRALE, OCS stratospheric lifetime is accurately determined. We found a lifetime of $70 \pm 20$ years at the polar latitude and $58 \pm 14$ years at the tropical latitude which leads to a mean global stratospheric lifetime of $64 \pm 17$ years. The global lifetimes is used to determine the stratospheric sink of OCS. In the lower stratosphere, the OCS stratospheric degradation produces $54 \pm 14 \mathrm{Gg} \mathrm{S} \mathrm{yr}^{-1}$. To go further, the contribution of OCS to the stratospheric aerosol burden should be more investigated by modeling study.

\section{Acknowledgements}

The authors thank the LPC2E technical team (L. Pomathiod, B. Gaubicher, G. Chalumeau, B. Coûté, T. Vincent, F. Savoie and G. Jannet, S. Chevrier) for the SPIRALE instrument preparation, the LPMAA technical team (I. Pépin, C. Rouillé and P. Marie-Jeanne) the SWIR-balloon instruments preparation, the CNES balloon launching team and the Swedish Space Corporation at Esrange for successful operations. The instrumental funding of the QualAir FTS was supported by the university Paris VI (Université Pierre et Marie Curie). The ETHER database (Pôle thématique du CNES-INSU-CNRS) and the "CNES sous-direction Ballon" are partners of the project. This work was supported by the European integrated project SCOUT-O3 (GOCE-CT-2004-505390), by the European Space Agency (ESA) as part of the Envisat validation program, by the French national LEFE/INSU project "UTLS Tropicale", by the French national Labex "VOLTAIRE" (ANR-10-LABX-100-01), by the "StraPolÉté" project funded by the "Agence Nationale de la Recherche (ANRBLAN08-1_31627), the "Centre National d'Etudes Spatiales (CNES), and the Institut Polaire Paul-Emile Victor (IPEV), and by the "ENRICHED" project funded by the 
CNES, INSU-CNRS and IPEV. The Atmospheric Chemistry Experiment (ACE), also known as SCISAT, is a Canadian-led mission mainly supported by the Canadian Space Agency. The data used in this publication were obtained as part of the Network for the Detection of Atmospheric Composition Change (NDACC) and are publicly available (see http://www.ndacc.org). Part of this work was performed at the Jet Propulsion Laboratory, California Institute of Technology, under contract with NASA. The authors thank also J. Notholt and O. Schrems for their data from the Polarstern campaign. We thank M. Coffey and J. Hannigan for their results from the P-AVE campaign.

\section{References}

Blake, N. J., Streets, D. G., Woo, J.-H., Simpson, I. J., Green, J., Meinardi, ... Blake, D. R. (2004). Carbonyl sulfide (OCS) and carbon disulfide (CS2): Large-scale distributions over the western Pacific and emissions from Asia during TRACE-P. J. Geophys. Res., 109, D15S05, doi:10.1029/2003JD004259.

Blake, N. J., Campbell, J. E., Vay, S. A., Fuelberg, H. E., Huey, L. G., Sachse, ... Blake, D. R. (2007). Carbonyl sulfide (OCS): Large-scale distributions over North America during INTEX-NA and relationship to $\mathrm{CO}_{2}$. J. Geophys. Res., 113, D09S90, doi:10.1029/2007JD009163.

Barkley, M. P., Palmer, P. I., Boone, C. D., Bernath, P. F., \& Suntharalingam, P. (2008). Global distributions of carbonyl sulfide in the upper troposphere and stratosphere. Geophys. Res. Lett., 35, L14810, doi:10.1029/2008GL034270.

Barletta, B., Meinardi, S., Simpson, I. J., Atlas, E. L., Beyersdorf, A. J., Baker, A. K., ... Blake, D. R. (2009). Characterization of volatile organic compounds (VOCs) in Asian and north American pollution plumes during INTEX-B: identification of specific Chinese air mass tracers. Atmos. Chem. Phys., 9, 5371-5388, doi:10.5194/acp-9-53712009.

Bates, T.S., Lamb, B.K., Guenther, A., Dignon, J \& Stoiber, R.E (1992). Sulfur Emissions to the Atmosphere from Natural Sources. Journal of Atmospheric Chemistry, 14, 315-337.

Bekki, S., and J. A. Pyle, 2-D assessment of the impact of aircraft sulphur emissions on the stratospheric sulphate aerosol layer, J. Geophys. Res., 97, 15839-15847, doi: 10.1029/92JD00770, 1992.

Bernath, P., McElroy, C.T., Abrams, M.C., Boone, C.D., Butler, M., Camy-Peyret, C., ... Zo, J. (2005). Atmospheric Chemistry Experiment (ACE): Mission overview. Geophys. Res. Lett., 32, L15S01, doi:10.1029/ 2005GL022386. 
Chin, M, \& Davis, D.D. (1993). Global sources and sinks of OCS and $\mathrm{CS}_{2}$ and their distributions. Global Biogeochem. Cycle, 7, 321-337.

Chin, M., \& Davis, D. D. (1995). A reanalysis of carbonyl sulfide as a source of stratospheric background sulfur aerosol. J. Geophys. Res., 100(D5), 8993-9005, doi:10.1029/95JD00275.

Clough, S. A., Shephard, M. W., Mlawer, E. J., Delamere, J. S., Lacono, M. J., Cady-Pereira, K., Boukabara, S., and Brown, P.D. (2005). Atmospheric radiation transfer modelling: A summary of the AER codes, short communication. J. Quant. Spectrosc. Radiat. Transfer, 91, 233-244.

Coffey, M. T., \& Hannigan, J. W. (2010). The temporal trend of stratospheric carbonyl sulphide. J. Atmos. Chem, 67, 61-70, doi: 10.1007/s10874-011-9203-4.

Crutzen, P.J. (1976). The possible importance of CSO for the sulfate layer of the stratosphere, Geophys. Res. Lett., 3, $73-76$.

Crutzen, P.J., and Schmailzl, U. (1983). Chemical budget of the atmosphere. Plant. Space. Sci., $31,1009-1032$.

DeMore, W.B., Sander, S.P., Golden, D.M., Hampson, R.F., Kurylo, M.J., Howard, C.J., ... \& Molina, M.J. (1997). Chemical kinetics and photochemical data for use in stratospheric modelling. in JPL Publication 97-4, Jet Propulsion Laboratory, Pasadena, CA.

Deutscher, N. M., Jones, N. B., Griffith, D. W. T., Wood, S. W., \& Murcray, F. J. (2006). Atmospheric carbonyl sulfide (OCS) variation from 1992-2004 by ground-based solar FTIR spectrometry, Atmos. Chem. Phys. Discuss., 6, 1619-1636, doi:10.5194/acpd-61619-2006.

Engel, A., \& Schmidt, U. (1994). vertical profile measurements of carbonyl sulfide in the stratosphere. Geophys. Res. Lett., 21, 2219-2222.

Finlayson-Pitts, B.J., \& Pitts, J.N. (2000). Chemistry of the upper and lower atmosphere theory, experiments and applications, chapter 3, Academic Press, San Diego.

Fueglistaler, S., Dessler, A. E., Dunkerton, T. J., Folkins, I., Fu, Q., \& Mote,P. W. (2009). Tropical tropopause layer. Rev. Geophys., 47, RG1004, doi:10.1029/2008RG000267.

Harrigan, D. L., Fuelberg, H. E., Simpson, I. J., Blake, D. R., Carmichael, G. R., \& Diskin, G. S. (2011). Anthropogenic emissions during Arctas-A: mean transport characteristics and regional case studies. Atmos. Chem. Phys., 11, 8677-8701, doi:10.5194/acp-11-8677-2011.

Hase, F., Hannigan, J.W., Coffey, M.T., Goldman, A., Höpfner, M., Jones, ... Wood, S.W. (2004). Intercomparison of retrieval codes used for the analysis of high-resolution: ground-based FTIR measurements. JQSRT, 87, 25-52. 
Junkermann, W., and W. R. Stockwell (1999). On the budget of photooxidants in the marine boundary layer of the tropical South Atlantic. J. Geophys. Res., 104(D7), 8039-8046, doi:10.1029/1998JD100060.

Kettle, A. J., Kuhn, U., von Hobe, M., Kesselmeier, J., \& Andreae, M. O. (2002a). Global budget of atmospheric carbonyl sulfide: Temporal and spatial variations of the dominant sources and sinks, J. Geophys. Res., 107, 4658, doi:10.1029/2002JD002187.

Kettle, A. J., Kuhn, U., von Hobe, M., Kesselmeier, J., Liss, P. S., \& Andreae, M. O., (2002b). Comparing forward and inverse models to estimate the seasonal variation of hemisphere-integrated fluxes of carbonyl sulphide. Atmos. Chem. Phys., 2, 343-361, doi:10.5194/acp-2-343-2002.

Krysztofiak, G., Thiéblemont, R., Huret, N., Catoire, V., Té, Y., Jégou, F., ... P., Camy-Peyret, C. (2012): Detection in the summer polar stratosphere of air plume pollution from East Asia and North America by balloon-borne in situ CO measurements. Atmos. Chem. Phys., 12, 11889-11906, doi:10.5194/acp-12-11889-2012.

Lejeune, B., Mahieu, E., Suntharalingam, P., Duchatelet, P., Servais, C., \& Demoulin, P. (2011). Trend evolution and seasonal variation of tropospheric and stratospheric carbonyl sulfide (OCS) above Jungfraujoch. EGU General Assembly 2011, Vol. 13, EGU2011-3536.

Leung, F. T., Colussi, A. J., Hoffmann, M. R., \& Toon, G. C. (2002). Isotopic fractionation of carbonyl sulfide in the atmosphere: Implications for the source of background stratospheric sulfate aerosol. Geophys. Res. Lett., 29(10), doi:10.1029/2001GL013955.

Marécal, V., Krysztofiak, G., Mébarki, Y., Catoire, V., Lott, F., Attié, ..., Robert, C. (2011). Impact of deep convection on the tropical tropopause layer composition in Equatorial Brazil. Atmospheric Chemistry and Physics, submitted.

Molina, L. T., Lamb, J. J., \& Molina, M. J. (1981). Temperature dependent UV absorption cross sections for carbonyl sulfide. Geophys. Res. Lett., 8(9), 1008-1011, doi:10.1029/GL008i009p01008.

Montzka S. A., Fraser, P.J. (lead authors) et al. (2003).Controlled substances and other source gases. Chapter 1 in Scientific Assessment of Ozone Depletion: 2002, Global Ozone Research and Monitoring Project-Report No. 47, World Meteorological Organization, Geneva.

Montzka, S. A., Reimann, S. (lead authors) et al. (2011). Ozone-Depleting Substances (ODSs) and Related Chemicals. Chapter 1 in Scientific Assessment of Ozone Depletion: 2010, Global Ozone Research and Monitoring Project—Report No. 52, World Meteorological Organization, Geneva. 
Moreau, G., Robert, C., Catoire, V., Chartier, M., Camy-Peyret, C., Huret, N., ... Chalumeau, G. (2005). A multispecies in situ balloon-borne experiment with six tunable diode laser spectrometers. Appl. Opt., 44(28), 5972-5989.

Notholt, J., Toon, G. C., Rinsland, C. P., Pougatchev, N. S., Jones, N. B., Connor, B. J, ... Schrems, O. (2000): Latitudinal variations of trace gas concentrations in the free troposphere measured by solar absorption spectroscopy during a ship cruise. J. Geophys. Res., 105(D1), 1337-1349, doi:10.1029/1999JD900940.

Notholt, J., Kuang, Z., Rinsland, C. P., Toon, G. C., Rex, M., Jones, N., ... O. Schrems. (2003). Enhanced Upper Tropical Tropospheric COS: Impact on the Stratospheric Aerosol Layer. Science 300, 307, doi : 10.1126/science.1080320.

Notholt, J.,Bingemer, H. (2006). Precursor gas measurements. SPARC (report No.4), Chapter 2, 29-76.

Plumb, R. A., \& Ko, M. K. W.: Interrelationships between mixing ratios of long-lived stratospheric constituents, J. Geophys. Res., 97, 10,145-10,156, 1992.

Revercomb, H.E., Buijs, H., Howell, H.B., LaPorte, D.D., Smith, W.L., \& Sromovsky, L.A. (1988). Radiometric calibration of IR Fourier transform spectrometers: solution to a problem with the High-resolution Interferometer Sounder. Appl. Opt., 27, 3210-3218.

Ricaud, P., Barret, B., Attié, J.-L., Motte, E., Le Flochmoën, E., Teyssèdre, H., ... Pommereau, J.-P. (2007). Impact of land convection on troposphere-stratosphere exchange in the tropics. Atmos. Chem. Phys., 7, 5639-5657, doi:10.5194/acp-7-56392007.

Rinsland, C. P., Goldman, A., Mahieu, E., Zander, R., Notholt, J., Jones, N. B., ... L. S. Chiou (2002). Ground-based infrared spectroscopic measurements of carbonyl sulfide: Free tropospheric trends from a 24 -year time series of solar absorption measurements. J. Geophys. Res., 107(D22), 4657, doi:10.1029/2002JD002522.

Roiger, A., Schlager, H., Schäfler, A., Huntrieser, H., Scheibe, M., Aufmhoff, H., ... Arnold, F. (2011). In-situ observation of Asian pollution transported into the Arctic lowermost stratosphere. Atmos. Chem. Phys., 11, 10975-10994.

Rothman, L.S., Gordon, I.E., Barbe, A., Benner, D.C., Bernath, P.F., Birk, M., ... Vander Auwera, J. (2009). The HITRAN 2008 molecular spectroscopic database. J. Quant. Spectrosc. Radiat. Transfer, 110, 533-572.

Rothman, L.S., Gordon, I.E., Babikov, Y., Barbe, A., Benner, D.C., Bernath, P.F., ... Wagner, G. (2013). The HITRAN 2012 molecular spectroscopic database. J. Quant. Spectroscop. Radiat. Transfer, http://dx.doi.org/10.1016/j.jqsrt.2013.07.002i, In Press.

Sander, S. P., Friedl, R. P., Abbatt, J. P. D., Barker, J. R., Burkholder, J. B., Golden, D. M, ... Orkin, V.L. (2011). Chemical Kinetics and Photochemical Data for Use in Atmospheric Studies Evaluation Number 17, JPL Publication 10-6. 
Seinfeld, J.H., \& Pandis, S.N.: Atmospheric chemistry and physics: from Air Pollution to Climate Change, chapter 7, Second edition, John Wiley \& Sons Ed, Inc., New York, 2006.

Simpson, I. J., Blake, N. J., Barletta, B., Diskin, G. S., Fuelberg, H. E., Gorham, K., ... Blake, D. R. (2010). Characterization of trace gases measured over Alberta oil sands mining operations: 76 speciated $\mathrm{C}_{2}-\mathrm{C}_{10}$ volatile organic compounds (VOCs), $\mathrm{CO}_{2}, \mathrm{CH}_{4}$, $\mathrm{CO}, \mathrm{NO}, \mathrm{NO}_{2}, \mathrm{NO}_{\mathrm{y}}, \mathrm{O}_{3}$ and $\mathrm{SO}_{2}$. Atmos. Chem. Phys., 10, 11931-11954, doi:10.5194/acp-10-11931-2010.

Té, Y., Jeseck, P., Camy-Peyret, C., Payan, S., Perron, G., \& Aubertin, G. (2002): Balloonborne calibrated spectroradiometer for atmospheric nadir sounding. Appl. Opt., 41, 64316441.

Té, Y., Jeseck, P., Pépin, I., \& Camy-Peyret, C. (2009). A method to retrieve blackbody temperature errors in the two points radiometric calibration Infrared. Physics \& Technology, 52, 187-192, doi:10.1016/j.infrared.2009.07.003.

Té, Y., Jeseck, P., Payan, S., Pépin, I., \& Camy-Peyret, C. (2010). The Fourier transform spectrometer of the UPMC University QualAir platform. Rev. Sci. Instrum., 81, 103102, doi:10.1063/1.3488357.

Té, Y., Jeseck, P., Dieudonné, E., Hase, F., Hadji-Lazaro, J., Clerbaux, C., ... Camy-Peyret, C. (2012). Carbon monoxide urban emission monitoring: a ground-based FTIR case study. Journal of Atmospheric and Oceanic Technology, Volume 29, Issue 7, Doi: 10.1175/JTECH-D-11-00040.1.

Toon, G.C. (1991): The JPL MkIV Interferometer. Opt. Photonics News, 2, 19-21.

Toon, G.C., Blavier, J.-F., Solario, J.N., Szeto, J.T. (1993). Airborne observation of the composition of the 1992 tropical stratosphere by the FTIR solar absorption spectrometry. J. Geophys. Res, 20, $2503-2506$.

Trenberth, K.E. \&, Smith, L. (2005). The mass of the atmosphere : A constraint on global analyses. J. of Clim., 18, $864-875$.

Turco, R.P., Whitten, R.C., Toon, O.B., Pollack, J.B., and Hamill, P. (1980). OCS, stratospheric aerosols and climate, Nature, 283, $283-286$.

Velazco, V. A., Toon, G. C., Blavier, J.-F. L., Kleinböhl, A., Manney, G. L., Daffer, W. H., ... Boone, C. (2011). Validation of the Atmospheric Chemistry Experiment by noncoincident MkIV balloon profiles. J. Geophys. Res., 116, D06306, doi:10.1029/2010JD014928.

Vernier, J.-P., Thomason, L. W., Pommereau, J.-P., Bourassa, A., Pelon, J., Garnier, A., ... Vargas, F. (2011). Major influence of tropical volcanic eruptions on the stratospheric aerosol layer during the last decade. Geophys. Res. Lett., 38, L12807, doi: $10.1029 / 2011 \mathrm{GL} 047563$. 
Xu, X., Bingemer, H. G., Georgii, H.-W., Schmidt, U., \& Bartell, U. (2001). Measurements of carbonyl sulfide (COS) in surface seawater and marine air, and estimates of the air-sea flux from observations during two Atlantic cruises. J. Geophys. Res., 106, 3491-3502, doi:10.1029/2000JD900571.

World Meteorological Organization (WMO) (1957): Meteorology: A threedimensional science. WMO Bull., 4, 134-138, Geneva, Switzerland.

Weisenstein, D. K., Yue, G. K., Ko, M. K. W., Sze, N. D., Rodriguez, J. M. and Scott, C. J. : A two-dimensional model of sulfur species and aerosol, J. Geophys. Res., 102, 1301913035, 1997.

Weisenstein, D., Bekki, S. (2006). Modeling of Stratospheric aerosols. SPARC (report No. 4), Chapter 6, 219-319.

Wilson, J.C., Lee, S.-H., Reeves, J. M., Brock, C. A., Jonsson, H. H., Lafleur, B. G. .. \& Moore, F. (2008). Steady-state aerosol distributions in the extra- tropical, lower stratosphere and the processes that maintain them. Atmos. Chem. Phys., 8, 6617-6626, doi:10.5194/acp8-6617-2008. 